\title{
Critically problematising existing organisational identity theory against practice: Part 2 - Organisational identity-in-action
}

\begin{tabular}{|c|c|}
\hline \multicolumn{2}{|c|}{$\begin{array}{l}\text { Authors: } \\
\text { Theo H. Veldsman }{ }^{1} \text { (1) } \\
\text { Dieter Veldsman }{ }^{1}\end{array}$} \\
\hline \multicolumn{2}{|c|}{$\begin{array}{l}\text { Affiliations: } \\
{ }^{1} \text { Department Of Industrial } \\
\text { Psychology and People } \\
\text { Management, College of } \\
\text { Management and Economic, } \\
\text { University of Johannesburg, } \\
\text { Johannesburg, South Africa }\end{array}$} \\
\hline \multicolumn{2}{|c|}{$\begin{array}{l}\text { Corresponding author: } \\
\text { Theo Veldsman, } \\
\text { theoveld@mweb.co.za }\end{array}$} \\
\hline \multicolumn{2}{|c|}{$\begin{array}{l}\text { Dates: } \\
\text { Received: } 17 \text { Mar. } 2020 \\
\text { Accepted: } 11 \text { Aug. } 2020 \\
\text { Published: } 29 \text { Oct. } 2020\end{array}$} \\
\hline \multicolumn{2}{|c|}{$\begin{array}{l}\text { How to cite this article: } \\
\text { Veldsman, T.H., \& Veldsman, D. } \\
\text { (2020). Critically } \\
\text { problematising existing } \\
\text { organisational identity theory } \\
\text { against practice: Part 2 - } \\
\text { Organisational identity-in- } \\
\text { action. SA Journal of } \\
\text { Industrial Psychology/SA } \\
\text { Tydskrif vir Bedryfsielkunde } \\
46(0), \text { a } 1800 \text {. https://doi. } \\
\text { org/10.4102/sajip.v46i0.1800 }\end{array}$} \\
\hline \multicolumn{2}{|c|}{$\begin{array}{l}\text { Copyright: } \\
\text { (c) 2020. The Authors. } \\
\text { Licensee: AOSIS. This } \\
\text { is licensed under the } \\
\text { Creative Commons } \\
\text { Attribution License. }\end{array}$} \\
\hline \multicolumn{2}{|l|}{ Read online: } \\
\hline 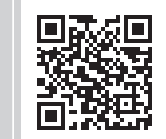 & $\begin{array}{l}\text { Scan this QR } \\
\text { code with your } \\
\text { smart phone or } \\
\text { mobile device } \\
\text { to read online. }\end{array}$ \\
\hline
\end{tabular}

Orientation: Organisations are embedded in an emerging world of work that is changing both radically and fundamentally. This context is forcing them to consider deeper issues, such as who are we? and why do we exist?

Research purpose: To critically review the power of the extant OI literature, with a view to providing deep insight into practice, based on the findings resulting from an OI intervention in a major global South African organisation. The aim is to critically problematise the current OI literature from a practice point of view. Part 2 of our article covers the here-and-now dynamics of OI, its evolution and change over time as well as OI-related outcomes, before concluding with the implications - for OI practice and theory - of our problematising review.

Motivation for the study: In the world of work, organisational identity (OI) has become critically important as a secure and referent anchor.

Research approach/design and method: Unconventional grounded theory was utilised. We moved the data generated from the lived, enacted experiences of participants to existing theory and then used the generated findings to question OI theory by validating, in an exploratory manner, the existing OI theory to expose the strengths, weaknesses and blind spots of the current literature from a practice/practitioner, power-of-understanding vantage point.

Main Findings: From a practice perspective, the OI literature was highly relevant, robust and valid in making sense of, and giving meaning to, what was observed during the OI intervention. Practice-wise, however, a number of significant weaknesses were also uncovered.

Practical/managerial implications: The OI literature - with the uncovered weaknesses rectified can assist greatly in strengthening OI work in practice.

Contribution/value-add: Theoretical and practical recommendations were made to strengthen the existing OI literature from a practice perspective.

Keywords: grounded theory; individual social identity; organisational identity; practiceproblematised theory; qualitative research.

\section{Introduction}

From a practice perspective, the radically and fundamentally changing world of work is forcing organisations and their members to address deeper issues, such as who are we? and why do we exist?, relative to the concepts of organisational and individual identities (Pioch \& Gerhard, 2014). Clear, robust identities, be they organisational or individual, provide secure and referent anchors in the present hyper-fluid and -turbulent world (Sillince \& Golant, 2018).

Theoretically, organisational identity (OI) is an integrative root concept located at the foundation of, and serving as a fulcrum point for, the field of organisational science (Ashforth, Harrison, \& Corley, 2008; Gioia, Patvardhan, Hamilton, \& Corley 2013; Gioia, Schultz, \& Corley, 2000; Haslam, Cornelissen, \& Werner, 2017; Pratt, Schultz, Ashforth, \& Ravashi, 2016). In some quarters, however, the value and utility of the concept of OI in practice - specifically in the emerging new world of work - are being questioned (Martínez, Pérez, \& Del Bosque, 2014).

Note: For Part 1, please visit: Veldsman, T.H. \& Veldsman, D. (2020). Critically problematising existing organisational identity theory against practice: Part 1 - The thinking framework of organisational identity. SA Journal of Industrial Psychology/SA Tydskrif vir Bedryfsielkunde 46(0), a1799. https://doi.org/10.4102/sajip.v46i0.1799 


\section{Research purpose and targeted literature}

The purpose of our research, reported on in a two-part article, was to perform a critical review of the existing literature on OI (and, to a lesser extent, individual identity) in terms of its current power to provide deep insights into practices related to this concept. To this end, we used the findings - generated within an adapted grounded theory research design - of a longitudinal organisational intervention by a major global South African organisation, which endeavoured to change its OI over 8 months as part of an overall turnaround strategy.

Our intention was to highlight both the strengths and the gaps in the current OI literature and to suggest how to enrich and extend the extant body of knowledge, both theoretically and practically. We, therefore, sought to problematise (Alvesson \& Sandberg, 2011) the current body of OI literature from a practice point of view in terms of its power of understanding, with the aim of strengthening (recursively speaking) both OI theory and practice.

Part 1 of our article described and reported on a large-scale OI intervention, before successively proceeding to critically problematise the current OI meta-theoretical lenses and OI vocabulary as well as the meta-theoretical framework applied to the territory called 'organisational identity'. In essence, Part 1 of our article dealt with the thinking framework of the existing OI literature (Veldsman \& Veldsman, 2020).

Part 2 of our article - in essence, OI-in-action: The 'application' side of the OI thinking framework - encompasses a critical problematisation of the existing OI literature, with respect to the here-and-now dynamics of OI, its evolution and the change over time and the outcomes of OI work. The article ends by highlighting the implications for OI practice and theory arising from our practice-referenced, problematising review of the pertinent literature.

\section{Research approach}

In both parts of our two-part article, we adopted conventional and unconventional grounded theory as the research design: 'unconventional', in that we did not primarily use the generated findings to build theory progressively but rather to validate - in an exploratory manner - the existing theory on OI (i.e. using extant literature). In doing so, we wished to expose its strengths, weaknesses and blind spots from a practice or practitioner power-of-understanding vantage point. Our intention was to open up new and deepened OI insights, both practically and theoretically, regarding OI across contexts, using a qualitative research design which is currently dominant in the field (Caza, Vough, \& Puranik, 2018).
We believe that we overcame the typical critiques against grounded theory as qualitative research approach (with respect to the replication and restricted generalisability of findings beyond the specific setting of the study), through: (1) the longitudinal nature of the findings reported on here 33 dialogue sessions covering all organisational members over 8 months (see below) and (2) adductive reasoning in a generalising manner, which set out to problematise the existing OI literature using our findings. In the process, OI theory provided us with the foundation for generalisation.

The findings used to problematise the existing OI literature were made in a global South African organisation within the hospitality and gaming industry (hereafter Organisation $\mathrm{ABC}$ ) that undertook the OI intervention reported on here. (For a detailed discussion of our research approach and the organisational intervention itself, see Part 1 of our article.)

First, however, a brief recap of the insights gained in Part 1 of our article, from our journey in critically problematising existing OI theory against practice, in terms of its power of understanding with respect to practice.

\section{Insights gained from, and implications of Part 1 of our critically problematising organisational identity journey}

The focus of Part 1 of our article was to critically problematise the thinking framework of the existing OI literature, in particular the current OI meta-theoretical lenses and the related vocabulary as well as the meta-theoretical framework applied to the territory called 'organisational identity'. The following three major insights and implications emerged from this part of our journey:

- First, in order to make proper sense of the richness and multidimensionality of OI, both in theory and in practice, it is imperative to employ multiple meta-theoretical lenses: not only the predominant functionalist lens but also the complexity/chaos, interpretivist and critical lenses.

- Second, the current OI vocabulary, which includes basic terms such as 'organisational identity', 'organisational image' (or reputation) and 'corporate identity' (or brand), appears at present to adequately facilitate the creation of a well-founded, comprehensive IO narrative.

- Third, the pressing need for an overarching, integrated metatheoretical framework (or 'Google map') of the territory called 'organisational identity'. The current OI literature is highly fragmented and silo-ed. We therefore set out to construct such a map from the extant literature in an attempt to understand OI in an integrated, systemic, holistic and organic manner, for both practical and theoretical purposes. We called the map the 'organisational identity landscape'. To provide a conceptual framework and foundation for Part 2 of our article, Figure 1 - presented in Part 1 of our article - depicts our envisaged OI landscape 


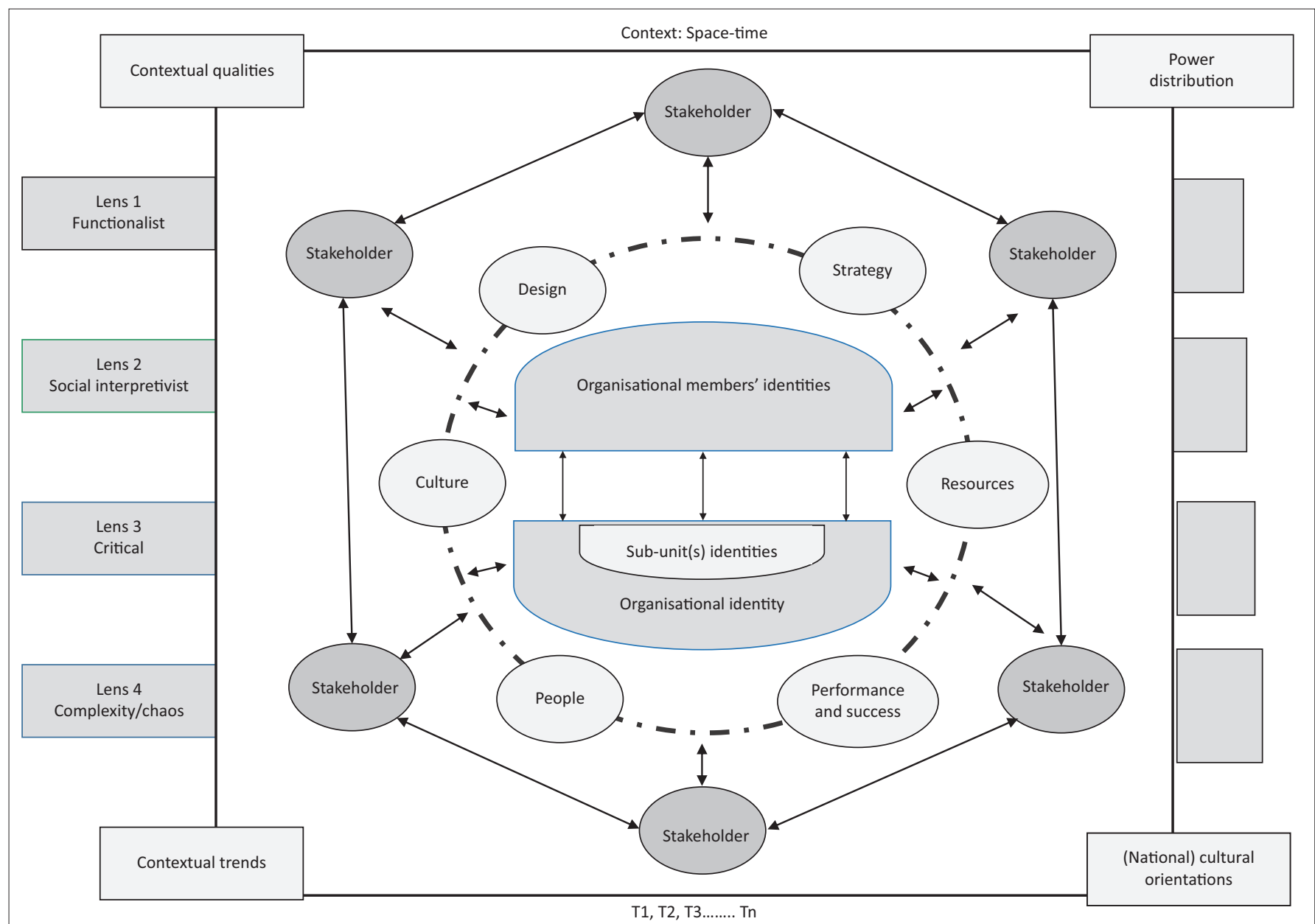

Source: Veldsman, T.H. \& Veldsman, D. (2020). Critically problematising existing organisational identity theory against practice: Part 1-The thinking framework of organisational identity. SA Journal of Industrial Psychology/SA Tydskrif vir Bedryfsielkunde 46(0), 7. https://doi.org/10.4102/sajip.v46i0.1799

FIGURE 1: Proposed Organisational Identity Landscape as meta-theoretical framework to map the territory called 'Organisational Identity'.

as an overarching, integrated meta-theoretical framework for the OI territory.

Against the backdrop of the above, reported insights gained from the critical problematising in Part 1 of our article, onwards with the balance of our journey of critically problematising the current OI literature from a practice perspective: the application of the thinking framework of current OI literature - OI-in-action, so to speak.

\section{Critical problematising of the here- and-now dynamics of organisational identity, as covered in the current organisational identity literature Durability and coherence of organisational identity}

The pertinent literature propounds two sets of views regarding the here-and-now dynamics of OI:

- Set 1: Durability of Organisational Identity (Alvesson, Ashcraft, \& Thomas, 2008; Ashforth \& Schinoff, 2016; Gioia et al., 2000, 2013; Kreiner, Hollensbe, Sheep, Smith, \& Kataria, 2015; Kreiner \& Murphy, 2016; Sillince \& Golant, 2018):
- View 1: Once formed, identity is static (or a given). It is a noun that finds expression in the core, distinctive and enduring attributes of the organisation - it is a way of being, a state.

- View 2: Identity is fluid (or in flow). It is an action term employed to describe the ongoing social construction of OI attributes in time - it is a way of becoming, a process.

- Set 2: Coherence of Organisational Identity (Alvesson et al., 2008; Scott \& Lane, 2000):

- View 1: Identity is integrated, enduring and a single entity.

- View 2: Identity is fragmented, consisting of manifold, simultaneous and shifting notions.

From the understanding we gained during the intervention, we realised that, at any given point in time, the here-andnow dynamics of organisational/individual identity are a relative mixture of all four views constituting the above two sets: organisational and individual identity work are, simultaneously, being and becoming, as well as integrating, singular and fragmented, shifting. This confirms the 'And/ Both' principle for which the complexity/chaos lens makes provision, instead of the 'Either/Or' principle of the 
functionalist lens. The literature and intervention served to confirm our fused position. In the literature, different terms are used to encapsulate this stance, including 'adaptive instability', 'dynamic consistency' and 'dynamic stability' (Ashforth, 2016b; Gioia et al., 2000; Hogg \& Terry, 2000; Kreiner \& Murphy, 2016; Schultz, 2016). Our preferred term is dynamic stability.

\section{Identity elasticity}

During identity work, a certain degree of identity elasticity influences the dynamic stability of OI: dialectical tensions in the ongoing social construction of OI over time concurrently striving to expand OI, whilst simultaneously keeping it the same. This is the tension in identity work, between identity as a noun (i.e., being) and as a verb (i.e., becoming) (Kreiner et al., 2015). Put differently, it is the tension between identity conceptualisation and identity contestation (Haslam et al., 2017) as identity work unfolds and progresses.

During the intervention, we witnessed this struggle as organisational members battled to relate to the aspirational identity, perceiving it to be inauthentic, whilst identifying more with the current identity that was 'familiar' and known, particularly at the sub-unit level. The still-active OI of the organisation's founders exacerbated this tension.

\section{Cycles of identity work}

Organisational and individual identity work (or construction) is the ongoing accomplishment of identification through recurring, self-adjusting and integrated cycles of formation, alignment and reinvention over time, as embedded in the OI landscape. Figure 2 depicts a suggested, ongoing, real-time, recurring cycle of identity work (Ashforth, 2016a; Ashforth \& Schinoff, 2016; Caza et al., 2018; Cornelissen, Haslam, \& Werner, 2016; Gioia et al., 2010; Schultz et al., 2012) as it takes place within that OI landscape. For the sake of simplicity, Figure 2 depicts an 'excerpt' from this landscape, notably a drill down into the two interacting identity circles at its centre (see Figure 1).

As is evident from Figure 2, identity work is multidimensional in that it (1) consists of the identity work cycle, for example sense giving; (2) occurs through different modes such as perceiving and interpreting; (3) happens at the conscious and unconsciousness levels; (4) takes place within a certain context and (5) unfolds over time, accommodating past, present and future (Caza et al., 2018). Because the identity work cycle in Figure 2 is embedded in the total OI landscape (see Figure 1), all of its constituent elements would reciprocally influence the cycle. Given the space constraints, we only pay attention to the identity work cycle as depicted in Figure 2 and then as applied solely to the intervention which focused on values as a key ingredientoforganisationalcultureas the 'operationalisation' of Organisation $\mathrm{ABC}^{\prime}$ s identity.
Frequently, the literature deals with the stages of identity work as single 'events', not as part of a cycle consisting of distinct stages as proposed here. During the intervention, we found the concurrent use of the complexity/chaos (i.e. emerging identity patterns), interpretivist (i.e. the co-creation of identity) and critical (i.e. who wields power and how, over identity work) lenses is invaluable for understanding, in a rich manner, the organic, here-and-now dynamics of identity work as it unfolded in successive stages.

We were able to confirm - through our observations during the intervention - the ongoing, reciprocal dependency and dialectical interactions and tensions around identity claims, which manifested in the unfolding identity work between organisational and individual identities, as reflected in the two-way arrows at the centre of Figure 2 (and also holistically, as per Figure 1). An important dynamic, which is indicative of the two-way arrows during identity work, was the shift from individual organisational members' intra-subjective identities, although their shared, internalised, inter-subjective OI, to an objectified, reified OI which took on a life of its own, independent of them (Haslam et al., 2017).

From our observations during the intervention, we confirmed that this shift was indeed at work, but then as understood against the backdrop of the reported tensions between the espoused OI, sub-unit identities and organisational members' identity experiences of all the aforementioned. There were similarities between how leaders and employees defined the aspirational OI. When delving into the behaviours associated with OI at a deeper value level, however, we noted significant differences in terms of how leaders and employees, respectively, saw the espoused, aspirational OI translating into behaviour indicators in practice: 'OI-in-action', in other words.

Observationally we can confirm that the shift outlined above was indeed at work in terms of organisational members perceiving, interpreting, feeling and doing, particularly at the conscious level. To the best of our knowledge, however, what is missing from the literature is an in-depth discussion of the simultaneously occurring dynamics - both consciously and unconsciously - involved in reciprocally interdependent identity work, in the concurrent crafting of organisational and individual social identities - much like braiding two strands of a single rope. What is also lacking in the OI literature is research into the enablers and barriers to identity work in all of its multidimensionality.

During the intervention, we focused on the interplay between the stages of sense breaking, sense giving and the internalisation of identity work (see Figure 2). In practice, we observed that these recursive stages did indeed exist. Organisation ABC intended to address the enactment and affirmation stages of identity work at a later time (although under different names). Translating the core values into behavioural indicators in Organisation ABC was already encroaching on the enactment stage. 


\section{Critical problematising of the evolution and change in organisational identity over time, as covered in the current organisational identity literature}

The here-and-now dynamics of identity work (discussed in the preceding section) deal with a single cycle in time, with respect to a single OI. Evolution and change move identity work through time in successive cycles, from one OI to another, on the timeline of past through present into future (T1, T2, T3...Tn): Given who we are at present, is this who we are becoming or should be becoming or want to become as an organisation, relative to our current/future expected context? Put differently: Who was I or were we? through to who am I or are we now? to who do I or we want to become or should we become?

In general, in the extant OI literature, authors pay relatively more attention to understanding the here-and-now dynamics of identity work: the single run through an identity work cycle with respect to a given OI. Far less attention is paid to identity work through time as an unfolding, evolving, largescale organisational change process, in moving from one OI to another, that can perhaps be entitled 're-identity' work (Caza et al., 2018). (For exceptions, see Bhatt, Van Riel, \& Baumann, 2016; Cuganesan, 2017; Gioia et al., 2010, 2013, who address this facet of identity work, mostly not as a largescale organisational change intervention but as an individual identity process.) The intervention we report on here - a large-scale OI change process occurring over a period of 8 months - highlighted this significant weakness in the current literature. The literature we consulted did not offer much to assist us in making post hoc sense of what was unfolding during the re-identity intervention over time in Organisation $\mathrm{ABC}$ from an organisational perspective.

Below we discuss our understanding of the unfolding reidentity work we observed, of replacing one OI with another in Organisation ABC, drawing on: (1) what little related OI literature is available on this theme; (2) the vast body of literature pertaining to large-scale organisational change; and (3) our theorising about re-identity work from a change perspective over time. Again, in combination, we found the complexity/chaos, interpretivist and critical lenses invaluable for making sense of the evolution and change in OI over time.

\section{Identify identity change triggers and gaps}

The evolution of, and change in, OI occur as and when a gap emerges between organisational and individual identities, because of a change in OI claims and/or referents. This gap may have different triggers:

- It is always present because identity work is ongoing over time, given its dynamic stability (see the discussion in the preceding section), and/or

- because of critical incidents such as times of major change, e.g., the emergence of the Viccas world (the term is elucidated in Part 1); the strategic repositioning of the organisation; a merger or acquisition; an organisational restructuring; an organisational legitimacy crisis amongst stakeholders or (recurring) micro-level incidents such as a challenge to self-understanding across time (Alvesson et al., 2008; Bhatt et al., 2016; Caza et al., 2018; Gioia et al., 2000, 2013; Kreiner \& Murphy, 2016).

The organisation may also re-craft its OI as it moves spontaneously and naturally through its life cycle stages (Johnson \& Jian, 2017). As mentioned, in the case of the reported intervention, the trigger was a deliberate turnaround strategy which the board of Organisation ABC initiated, requiring a change in its $\mathrm{OI}$.

Table 1 depicts the different permutations of gaps in identity, between the organisation and individuals, which may emerge over time. These observed gaps emerged during the dialogue sessions and were aggregated from an organisational perspective, to present collectively shared gaps. The change challenge is that the gap may not be the same for all individuals. Also, if the organisation has multiple identities, the gap may not only look different across the organisation but also be different for individuals. The biggest gap will occur where both the desired future organisational and individual identities simultaneously differ from what they are at present. The gap which Organisation ABC had to address, as it became apparent during the intervention, is indicated in Table 1 as italicised text.

Because of competing organisational claims and referents, an identity gap can be characterised by the to-be-resolved tensions which are indicative of the intense dialectics of identity work over time:

- What is essential vs. negotiable (core OI feature)

- What is consistent vs. changeable (enduring OI feature)

- What separates or links who are we? relative to other organisations (distinctive OI feature).

Alternatively, how can we reinterpret and translate the essence of the present - that which is core, enduring and distinctive - to fit new contexts and demands, so as to remain relevant? Put differently, it is the tension arising from

TABLE 1: Potential permutations of gaps in identity between the organisation and individuals.

\begin{tabular}{|c|c|c|c|}
\hline \multirow[t]{2}{*}{ Change gap or need } & \multirow[t]{2}{*}{ Variable } & \multicolumn{2}{|c|}{ Organisational identity } \\
\hline & & Present identity claims: Who are we now? & $\begin{array}{l}\text { Future identity claims (vision): Who do we want to be/ } \\
\text { should we be in the future? }\end{array}$ \\
\hline \multirow[t]{2}{*}{$\begin{array}{l}\text { Identities of organisational } \\
\text { member(s) }\end{array}$} & Present identity claims: Who am I now? & $\begin{array}{l}\text { - Organisation-member: Same/different } \\
\text { identity }\end{array}$ & $\begin{array}{l}\text { - Organisation: Same/different identity } \\
\text { - Organisation-member: Same/different identity }\end{array}$ \\
\hline & $\begin{array}{l}\text { Future identity claims (Vision): Who do I } \\
\text { want to be/should I be in the future? }\end{array}$ & $\begin{array}{l}\text { - Member: Same/different } \\
\text { - Member \& organisation: Same/different } \\
\text { identity }\end{array}$ & - Member \& organisation: Same/different identity \\
\hline
\end{tabular}


embracing change whilst remaining the same (Ashforth, 2016b; Gioia et al., 2000, 2013; Golant, Sillince, Harvey, \& Maclean, 2015; Hogg \& Terry, 2000; Kreiner \& Murphy, 2016; Schultz, 2016), the challenge of optimal distinctiveness (Zuckerman, 2016).

The degree of inertia or resistance to OI change is a function of the strength of the innate identity features (namely, core, endurance, and distinctiveness), and how deeply and widely they are entrenched in components such as the core values of the organisational culture (Gioia et al., 2013).

During the intervention we found that, in the current state, organisational members experienced a 'sameness' regarding identity, but this 'sameness' contrasted with the prevailing yet different current broader organisational view of who were we? Organisational members viewed the future identity state as far less aligned with different members' or organisational views of who are we becoming?

\section{Define the identity-change need and craft a change navigation strategy}

After demarcating the identity gap, it is important to correctly define the identity-change need (Brown, 2015; Humphreys \& Brown, 2002; Van Tonder, 2004). Table 2 gives a menu of potential identity-change needs, using a well-known, largescale change-need typology to categorise those needs (Nadler \& Tushman, 1995).

During the intervention, we defined the identity-change need as a re-creation: identity change, being both discontinuous

TABLE 2: Typology of identity-change needs.

\begin{tabular}{lll}
\hline Variable & Incremental & Discontinuous \\
\hline Proactive & $\begin{array}{l}\text { Tuning: } \\
\text { - Identity validation: Let's make } \\
\text { sure who we are } \\
\text { - Identity maintenance: Let's } \\
\text { protect who we are }\end{array}$ & $\begin{array}{l}\text { Re-creating: } \\
\text { - Identity change: Let's find a new } \\
\text { identity }\end{array}$ \\
Reactive & $\begin{array}{l}\text { Adapting: } \\
\text { - Identity alignment: Let's all } \\
\text { agree who we are }\end{array}$ & $\begin{array}{l}\text { Re-orientating: } \\
\text { - Identity elaboration: Let's } \\
\text { strengthen and enrich our } \\
\text { understanding of who we are }\end{array}$ \\
\hline
\end{tabular}

and proactive with respect to finding a new identity for Organisation $\mathrm{ABC}$. This is the most radical identity-change need that can be addressed, as moderated by the aforementioned identity gap. In essence, the need was for all organisational members to re-imagine Organisation ABC's identity.

Once we had defined the identity-change need, we had to craft an OI change navigation strategy which would be able to address the identity need and successfully close the gap. The change strategy had to accommodate design parameters such as bottom-up and or top-down; events or process driven; exclusive or inclusive; planned or spontaneous; participative or directive (Bhatt et al., 2016; Kreiner \& Murphy, 2016; Veldsman, 2002). The current OI literature is essentially silent on this topic, because the focus is on identity work from an individual perspective. Of course this also assumes, as a departure point, the adoption of a change navigation thinking framework to inform the change navigation strategy (e.g. dialogical, complex adaptive) (cf. Bushe \& Marshak, 2015).

We thus had to choose specific change interventions. During the intervention, the large-scale change navigation strategy was both top-down and bottom-up, with various interventions - including storytelling during dialogue sessions - and different avenues of implementation.

\section{Critical problematising of the outcomes of organisational identity work, as covered in the current organisational identity literature}

Table 3 summarises the outcomes of a strong OI (positive and negative) for both the organisation and its members, as reported in the literature. Outcomes are depicted graphically in Figure 2 as two-way arrows between the identity work cycle, on the one hand, and the organisational/ sub-unit and individual identities on the other.

TABLE 3: Outcomes of a strong organisational identity for the organisation and organisational members.

\begin{tabular}{|c|c|c|}
\hline Variable & Positive & Negative (dark side of identity) \\
\hline Organisation (external referral) & $\begin{array}{l}\text { - Common fate and destiny } \\
\text { - Acceptance of organisational intentions, goals and values } \\
\text { - Task performance: Willingness to work hard for organisation } \\
\text { - High engagement and job involvement } \\
\text { - Teamwork/cooperation } \\
\text { - Organisational and team commitment } \\
\text { - Organation sharing } \\
\text { - Perceived organitizational fairness } \\
\text { - Work adjustment and well-being } \\
\text { - Lower withdrawal and turnover/turnover intentions }\end{array}$ & $\begin{array}{l}\text { - Management tool to gain and maintain control over organisational } \\
\text { members and ensure compliance and subordination } \\
\text { - Groupthink } \\
\text { - Negative in-/out-group dynamics } \\
\text { - Continued commitment to a failing project } \\
\text { - Overdependence on leader with whom one identifies } \\
\text { - Less perceived need to interverse in questionable behaviour } \\
\text { - Suppressing dissent when doubt is called for } \\
\text { - Impeded organisational learning and adaptation }\end{array}$ \\
\hline $\begin{array}{l}\text { Organisational member (internal } \\
\text { self-referral vis-à-vis own identity) }\end{array}$ & $\begin{array}{l}\text { - Positive in terms of self-image, enhancement, knowledge, esteem, } \\
\text { - efficacy, verification and continuity } \\
\text { - Clearer sense of meaning and purpose } \\
\text { - Sense of belonging } \\
\text { - Self-sacrifice } \\
\text { - Choices in best interests of organisation } \\
\text { - Pro-change } \\
\text { - Job satisfaction } \\
\text { - Life satisfaction } \\
\text { Defence of organisation }\end{array}$ & $\begin{array}{l}\text { - Work-alcoholism } \\
\text { - Uncritical } \\
\text { - Uning } \\
\text { - Resistancal behaviour on behalf of organisation } \\
\text { - Work-to-family conflict } \\
\text { - Lack of objectivity } \\
\text { - Inability to question the ethics of organisational behaviour } \\
\text { - Wellbeing }\end{array}$ \\
\hline
\end{tabular}

Source: Please see the full reference list of the article for more information. Compiled from: Alvesson and Robertson (2016); Ashforth (2016a, 2016b); Ashforth and Schinoff (2016); Ashforth, Schinoff and Rogers (2016); Avanzi, Van Dick, Fraccaroli and Sarchielli (2012); Conroy, Henle, Shore and Stelman (2017); De Moura, Abrams, Retter, Gunnarsdottir and Ando (2009); Edwards (2005); Humphreys and Brown (2002); Lee, Park and Koo (2015); Li, Fan and Zhao (2015); Van Tonder (2004). 


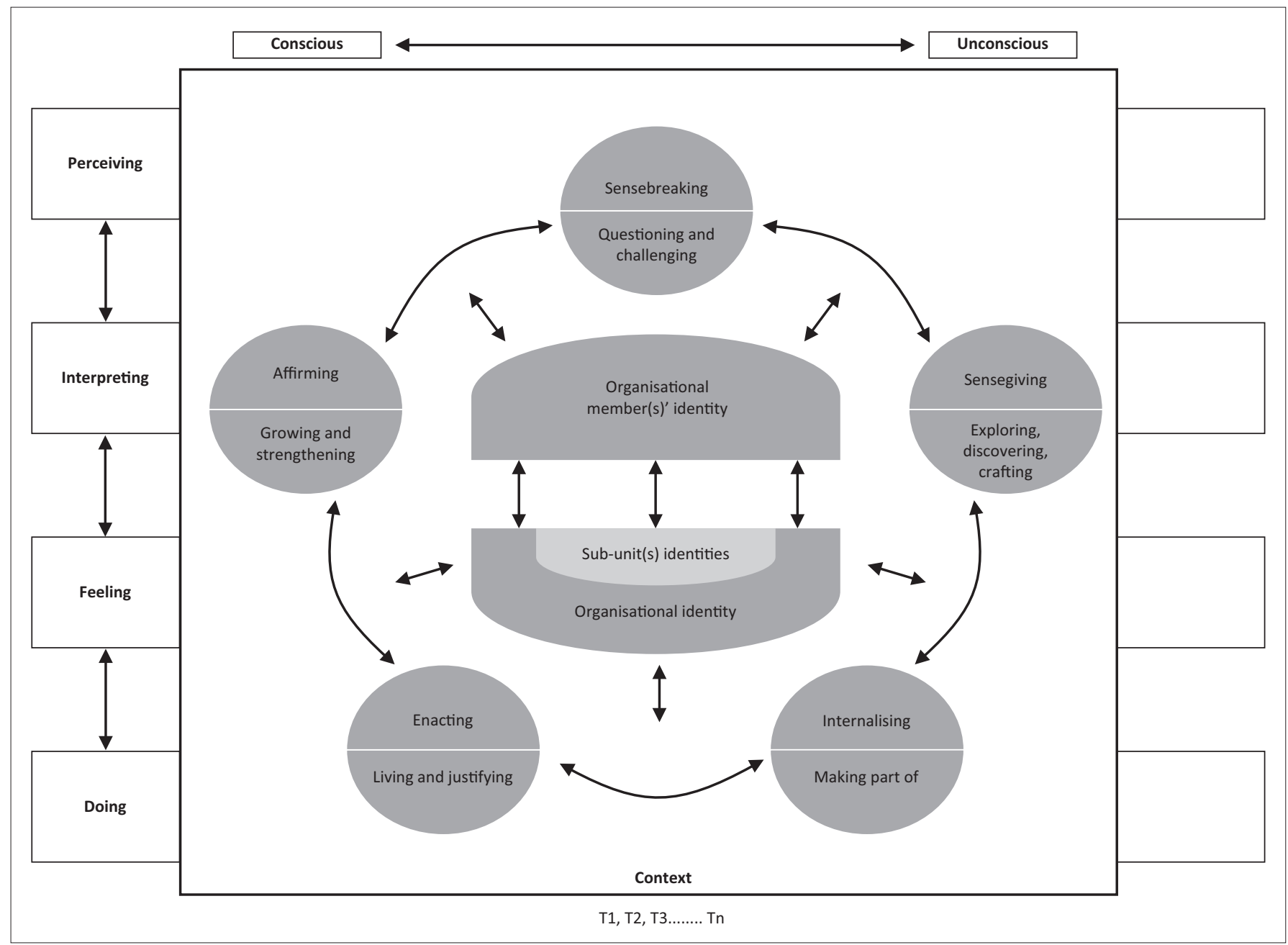

FIGURE 2: Ongoing, real-time recurring cycle of identity work.

Using italics in Table 3 we highlight the outcomes observed in the course of the intervention. A limitation of what is presented in Table 3 is that the outcomes are listed as standalones (i.e. 'snapshots').

In terms of the complexity/chaos lens, outcomes form reciprocal relationships of effects/counter-effects, settling into patterns over time (the OI 'movie') that can be virtuous or vicious with respect to organisational and individual functioning. Conceiving and validating such postulated patterns - a 'theory of patterned OI outcomes' - is a real need in moving the current OI literature forward, practically speaking.

As regards positive organisational outcomes, during the intervention we found that identity crafting contributed towards creating a common fate and destiny for organisational members, through a shared vision, values and goals. A sense of team and organisational citizenship helped to nurture the process. On the negative side, we noted that - in a context of distrust - the leadership of Organisation ABC used identity crafting as a management tool to drive, and even enforce, subordinate compliance. Groupthink also emerged in the latter stages of the intervention, with identity inputs becoming similar in every way to those of the dominant organisational members who seemingly influenced and determined the views of the majority.

Historically, identifying with a single founding leader as the source of the original OI seemed ingrained in the very DNA of Organisation ABC. Organisational members struggled to let go of the bygone era that had been built around specific leaders whom they revered as heroes and legends in the ongoing organisational narrative (see Powell \& Baker [2017] on the role of founders in OI).

At an individual level, clearly the process was creating meaning for members of Organisation ABC, as was the sense of belonging they experienced as part of the OI crafting process. On the negative side, a lack of objectivity posed a risk for the crafting of authentic organisational and individual identities with which members could identify. This resonated with the outcome of groupthink, which emerged at the organisational level.

Using multiple lenses to understand the OI outcomes of the intervention again proved invaluable in making sense of the findings: we looked at the outcomes (holistically, integratively) as a dynamic pattern of a virtuous/vicious 
cycle reflecting the interactions of stakeholders/leadership/ organisational members (complexity/chaos lens); we noted the extent of the shared meanings which organisational members attributed to outcomes (interpretivist lens); and how leadership controlled identity work to arrive at (predefined) desired outcomes and their imposed ascription of relative worth to those outcomes (critical lens). The current OI literature does not, however, offer insight into the holistic, reciprocal interdependencies of OI outcomes and their configurations into virtuous or vicious cycles of interaction.

\section{Insights gained from Part 2 of our critically problematising organisational identity journey}

This concludes our journey of critically problematising the current OI literature from a practice perspective, in terms of its practice/practitioner, power-of-understanding, capability. In Part 2 of our article reflecting on this journey - focusing on OI-in-action, the application of its thinking framework - we gained the following, further insights:

- First, at any given point in time, the here-and-now dynamics of organisational/individual identity - identity work - is a relative mixture of simultaneously (1) being and becoming and (2) integrating, singular and fragmented, shifting. This confirmed for us the value of a 'And/Both' view for which the complexity/chaos lens makes provision, instead of the 'Either/Or' view of the functionalist lens.

- Second, in general, the OI literature deals with the stages of identity work as single 'events'. Identity work is not seen as part of the ongoing accomplishment of identification through recurring, self-adjusting and integrated cycles of formation, alignment and reinvention over time, consisting of distinct stages as we saw through our practice-based observations.

- Third, during the intervention, we found the concurrent use of multiple lenses to make sense of the identity work by applying complexity/chaos (i.e. emerging identity patterns), interpretivist (i.e. the co-creation of identity) and critical (i.e. who wields power and how, over identity work) lenses invaluable for understanding, in a rich manner, the organic, here-and-now dynamics of identity work as it unfolded in stages. The functionalist lens was unable to provide such rich insights.

- Fourth, compared to the here-and-now dynamics of OI at the individual level, the extant OI literature - with a few rare exceptions - does not cover identity work as an unfolding, evolving, large-scale organisational change process, from a truly organisational perspective. Individual identity work reigns supreme. We had to source literature on large-scale organisational change to construct the identity route map of Organisation $\mathrm{ABC}$ through time and make sense of it as the change journey unfolded.

- Fifth, in terms of OI outcomes, the existing OI literature presents one-on-one, linear cause-and-effect relationships (identity 'snapshots') between antecedents (elements), moderators of identity and outcomes. However, we observed multiple outcomes which were active at the same point in time, forming reciprocal relationships of effects/counter-effects, settling into patterns (an OI 'movie') that were virtuous or vicious with respect to organisational and individual functioning. This observation resonates strongly with a complexity/chaos lens. Conceiving of, and validating, such postulated patterns - a 'theory of patterned OI outcomes' - is a real need in moving the current OI literature forward, practically speaking. In practice, organisations have to deal with OI outcomes, holistically, systemically and organically.

\section{Conclusion: Implications for organisational identity practice and theory arising from our practice- referenced, problematising review of the existing organisational identity literature}

Organisational and individual identities have moved centre stage in a Viccas world, where identity, in all its manifestations, is under severe threat. Paradoxically, however, identity has provided (and can provide) a secure and referent anchor in this world, for both organisations and individuals. Our article sets out to push the knowledge frontiers around identity by reciprocally fusing theory and practice within a mostly ignored context, namely, that of (South) Africa.

We used the findings from an intervention we were involved in to validate - critically and in an exploratory manner - the existing theory regarding OI, to arrive at enriched insights into both the strengths of, and gaps in, the related literature, in practice and in theory. What remains, in conclusion, is to draw out implications for the field of OI, going forward. We first focus on practical and then theoretical implications.

\section{Practical implications}

From a practice perspective, three implications emerged: first, it seems more effective to change OI from a sub-unit level upwards to an organisational level, which is counterintuitive and contrary to current thinking around large-scale OI change navigation. We have to consider this implication in future related change navigation approaches, which currently (as a rule) focus on top-down, leader-led strategies. The reported intervention strongly pointed to the need for a dual change strategy and approach with respect to OI change navigation: the simultaneous merging of bottom-up and top-down change.

Second, the intervention further revealed a need for an allembracing, coherent OI narrative, incorporating both the psycho-social and cultural sides of the organisation as they relate to beliefs, values, norms and perceptions (the 'software' 
of the organisation and its members) and, simultaneously, incorporating organisational processes, policies and measures (the organisation's 'hardware'). Only in this way will we objectively and subjectively create an authentic experience of the reinvented OI. In essence, If we say we are different, we need to look different, feel different and act different simultaneously, in order to become and be something different. By implication, the aforesaid reinforces the need to look at OI holistically, systemically and organically - in our terminology, by applying the total OI landscape seamlessly, using a complexity lens.

Third, the intervention demonstrated that OI change identity work - is an ever-changing, iterative, intensive longitudinal process that occurs over an extended period of time. We must manage expectations within organisations, and amongst leadership, by communicating to them that identity work, and the intended benefits achievable through an OI crafting process, require a long-term commitment and sufficient resources. There is no silver bullet.

\section{Theoretical implications}

From a theoretical perspective, first, the value and necessity of using multiple lenses concurrently to understand OI, both theoretically and practically, became clear, given its richness and multifaceted nature. Second, there is a need for a metaframework - our proposed OI landscape - to accommodate and make sense of the richness and complexity of the field and its empirical findings. Third, it is imperative that we develop a fully fledged, OI-specific, large-scale change navigation process to complement the individual identity work bias in the current OI literature. Fourth, we need to conceive of, and validate, a predictive theory of patterned OI outcomes. Fifth (although not addressed in our problematising critical review), there is an urgent need, going forward, to incorporate into our OI theorising and practice the consequences of fundamental, radical shifts in the emerging new world order and world of work, for identity and identity work. These shifts are represented by, for example, globalisation, interconnectivity, virtualisation, digitisation and automation, arising out of, inter alia, the Fourth Industrial Revolution (Veldsman, 2016). The relevant literature has not, in any significant way, incorporated or addressed these shifts. An exception in this regard is a recent study into OI for on-demand workers, reflective of the emerging new world of work (Rockmann \& Ballinger, 2017).

All in all, our problematising critical review of the current OI literature from a practice perspective has unequivocally demonstrated the importance, robustness and relevancy of OI in practice, in industrial and organisational psychology. Herein lies, we believe, the significant contribution of our research: the critique of theory from practice, in order to strengthen the former.

Relative to real strengths in the existing OI literature, however, some critical weaknesses practice-wise have to be addressed, as highlighted in our two-part article. These weaknesses offer clear clues to future OI research opportunities. Given the vast scope of the current OI literature, the overarching limitation of our critical review is that we may have missed a key theoretical insight, which could have enriched the review substantively. In that respect, our review is open-ended, and we extend an invitation to other practitioners to share their experiences of the practice power of understanding of the existing OI theory.

\section{Acknowledgements Competing interests}

The authors have declared that no competing interest exist.

\section{Authors' contributions}

All authors contributed equally to this work.

\section{Ethical consideration}

This article followed all ethical standards for carrying out research.

\section{Funding information}

This research received no specific grant from any funding agency in the public, commercial or not-for-profit sectors.

\section{Data availability statement}

The authors confirm that the data supporting the findings of this study are available within the article.

\section{Disclaimer}

The views and opinions expressed in this article are those of the authors and do not necessarily reflect the official policy or position of any affiliated agency of the authors.

\section{References}

Alvesson, M., Ashcraft, K.L., \& Thomas, R. (2008). Identity matters: Reflections on the construction of identity scholarship in organisation studies. Organisation, 15(1), 5-28. https://doi.org/10.1177/1350508407084426

Alvesson, M., \& Robertson, M. (2016). Organisational identity: A critique. In M.G. Pratt, M. Schultz, B.E. Ashforth, \& D. Ravashi (Eds.), The Oxford handbook of organisational identity (pp. 160-180). Oxford: Oxford University Press.

Alvesson, M., \& Sandberg, J. (2011). Generating research questions through problematization. Academy of Management Review, 36(2), 247-271. https://doi. org/10.5465/amr.2009.0188

Ashforth, B.E. (2016a). Distinguished scholar invited essay: Exploring identity and identification in organisations - Time for some course corrections. Journal of Leadership \& Organisational Studies, 23(4), 361-373. https://doi.org/ $10.1177 / 1548051816667897$

Ashforth, B.E. (2016b). Organisational, sub-unit and individual identities. In M.G. Pratt, M. Schultz, B.E. Ashforth, \& D. Ravashi (Eds.), The Oxford handbook of organisational identity (pp. 79-92). Oxford: Oxford University Press.

Ashforth, B.E., Harrison, S.H., \& Corley, K.G. (2008). Identification in organisations: An examination of four fundamental questions. Journal of Management, 34(3), 325-374. https://doi.org/10.1177/0149206308316059

Ashforth, B.E., \& Schinoff, B.S. (2016). Identity under construction: How individuals come to define themselves in organisations. Annual Review of Organisational Psychology and Organisational Behavior, 3(1), 111-137. https://doi.org/10.1146/ annurev-orgpsych-041015-062322 
Ashforth, B.E., Schinoff, B.S., \& Rogers, K.M. (2016). 'I identify with her', 'I identify with him': Unpacking the dynamics of personal identification in organizations. Academy of Management Review, 41(1), 28-60. https://doi.org/10.5465/ Academy of

Avanzi, L., Van Dick, R., Fraccaroli, F., \& Sarchielli, G. (2012). The downside of organisational identification: Relations between identification, workaholism and well-being. Work \& Stress, 26(3), 289-307. https://doi.org/10.1080/02678373.20 well-being.

Bhatt, M., Van Riel, C.B.M., \& Baumann, M. (2016). Planned organisational identity change: Insights from practice. In M.G. Pratt, M. Schultz, B.E. Ashforth, \& D. Ravashi (Eds.). The Oxford handbook of organisational identity (pp. 219-238) Oxford: Oxford University Press.

Brown, A.D. (2015). Identities and identity work in organisations. International Journal of Management Review, 17(1), 20-40. https://doi.org/10.1111/ijmr.12035

Bushe, G.R., \& Marshak, R.J. (Eds.). (2015). Dialogic organisation development: The theory and practice of transformational change. Oakland, CA: Berrett-Koehler.

Caza, B.B, Vough, H., \& Puranik, H. (2018). Identity work in organisations and occupations: Definitions, theories, and pathways forward. Journal of Organisational Behavior, 39(7), 889-910. https://doi.org/10.1002/job.2318

Conroy, S., Henle, C.A., Shore, L., \& Stelman, S. (2017). Where there is light, there is dark: A review of the detrimental outcomes of high organisational identification Journal of Organisational Behavior, 38(2), 184-203. https://doi.org/10.1002/ job. 2164

Cornelissen, J.P., Haslam, S.A., \& Werner, M.D. (2016). Bridging and integrating theories on organisational identity: A social interactionist model of organisational identity formation and change. In M.G. Pratt, M. Schultz, B.E. Ashforth, \& D. Ravashi (Eds.), The Oxford handbook of organisational identity (pp. 200-215) Oxford: Oxford University Press.

Cuganesan, S. (2017). Identity paradoxes: How senior managers and employee negotiate similarity and distinctiveness tensions over time. Organisation Studies, 38(3/4), 489-511. https://doi.org/10.1177/0170840616655482

De Moura, G.R., Abrams, D., Retter, C., Gunnarsdottir, S., \& Ando, K. (2009). Identification as an organisational anchor: How identification and job satisfaction combine to predict turnover intention. European Journal of Social Psychology, 39(4), 540-557. https://doi.org/10.1002/ejsp.553

Edwards, M.R. (2005). Organisational identification: A conceptual and operational review. International Journal of Management Reviews, 7(4), 207-230. https://doi org/10.1111/j.1468-2370.2005.00114.x

Gioia, D.A., Patvardhan, S.D., Hamilton, A.L., \& Corley, K.G. (2013). Organisational identity formation and change. Academy of Management Annals, 7(1), 123-192. https://doi.org/10.5465/19416520.2013.762225

Gioia, D.A., Price, K.N., Hamilton, A.L., \& Thomas, J.B. (2010). Forging an identity: An insider-outsider study of processes involved in the formation of organisational identity. Administrative Science Quarterly, 55(1), 1-46. https://doi.org/10.2189/ identity. Administrat
asqu.2010.55.1.1

Gioia, D.A., Schultz, M., \& Corley, K.G. (2000). Organisational identity, image and adaptive instability. Academy of Management Review, 25(1), 63-87. https://doi. org/10.2307/259263

Golant, B.D., Sillince, J.A.A., Harvey, C., \& Maclean, M. (2015). Rhetoric of stability and change: The organisational identity work of institutional leadership. Human Relations, 68(4), 607-631. https://doi.org/10.1177/0018726714532966

Haslam, S.A., Cornelissen, J.P., \& Werner, M.D. (2017). Meta-theories and metaphors of organisational identity: Integrating social constructionist, social identity, and social actor perspectives within a social interactionist model. International Journa of Management Reviews, 19(3), 318-336. https://doi.org/10.1111/ijmr.12150

Hogg, M.A., \& Terry, D.J. (2000). The dynamic, diverse and variable faces of organisational identity. Academy of Management Review, 25(1), 150-154. https:// doi.org/10.5465/amr.2000.27711645

Humphreys, M., \& Brown, A.D. (2002). Narratives of organisational identity and identification: A case study of hegemony and resistance. Organisation Studies, 23(3), 421-447. https://doi.org/10.1177/0170840602233005

Johnson, T.L., \& Jian, G. (2017). Understanding organisational identity development across the lifecycle in an emerging faith-based organisation: A case analysis. Southern Communication Journal, 82(3), 185-197. https://doi.org/10.1080/1041 794X.2017.1315449
Kreiner, G.E., Hollensbe, E.C., Sheep, M.L., Smith, B.R., \& Kataria, N. (2015). Elasticity and the dialectic tensions of organisational identity: How can we hold together while we are pulling apart? Academy of Management Journal, 58(4), 981-1011. while we are pulling apart? Academy of
$\mathrm{https}: / /$ doi.org/10.5465/amj.2012.0462

Kreiner, G.E., \& Murphy, C. (2016). OI work. In M.G. Pratt, M. Schultz, B.E. Ashforth, \& D. Ravashi (Eds.), The Oxford handbook of organisational identity (pp. 436-454). Oxford: Oxford University Press.

Lee, E.S., Park, T.Y., \& Koo, B. (2015). Identifying organisational identification as a basis for attitudes and behaviours: A meta-analytic review. Psychological Bulletin, 141(5), 1049-1080. https://doi.org/10.1037/bul0000012

Li, Y., Fan, J., \& Zhao, S. (2015). Organisational identification as a double-edged sword: Dual effects on job satisfaction and life satisfaction. Journal of Personnel Psychology, 14(4), 182-191. https://doi.org/10.1027/1866-5888/a000133

Martínez, P., Pérez, A., \& Del Bosque, I.R. (2014). Exploring the role of CSR in the organizational identity of hospitality companies: A case from the Spanish tourism industry. Journal of Business Ethics, 124(1), 47-66. https://doi.org/10.1007/ s10551-013-1857-1

Nadler, D.A., \& Tushman, M.L. (1995). Types of organisational change: From incremental improvements to discontinuous transformation. In D.A. Nadler, R.S. Shaw, A.E. Walton, \& Associates (Eds.), Discontinuous change (pp. 14-34). San Francisco, CA: Jossey-Bass.

Pioch, E.A., \& Gerhard, U. 2014. Organizational culture as differentiator in international retailing. Service Industries Journal, 34(8), 729-749. https://doi.org/10.1080/026 42069.2014.886194

Powell, E.E., \& Baker, T. (2017). In the beginning: Identity processes and organizing in multi-founder nascent ventures. Academy of Management Journal, 60(6), 2381-2414. https://doi.org/10.5465/amj.2015.0175

Pratt, M.G., Schultz, M., Ashforth, B.E., \& Ravashi, D. (2016). Introduction: Organisational identity, mapping where we have been, where we are, and where we might go. In M.G. Pratt, M. Schultz, B.E. Ashforth, \& D. Ravashi (Eds.), The Oxford handbook of organisational identity (pp. 1-18). Oxford: Oxford University Press.

Rockmann, K.W., \& Ballinger, G.A. (2017). Intrinsic motivation and organisational identification among on-demand workers. Journal of Applied Psychology, 102(9), 1305-1316. https://doi.org/10.1037/apl0000224

Schultz, M. (2016). Organisational identity change and temporality. In M.G. Pratt, M. Schultz, B.E. Ashforth, \& D. Ravashi (Eds.), The Oxford handbook of organisational identity (pp. 93-105). Oxford: Oxford University Press.

Schultz, M., Maguire, S., Lanley, A., \& Tsoukas, H. (2012). Constructing identity in and around organisations: Introducing the second volume on perspectives on proces organisational studies. In M. Schultz, S. Maguire, A. Lanley, \& H. Tsoukas (Eds.) Constructing identity in and around organisations (pp. 1-20). Oxford: Oxford University Press.

Scott, S.G., \& Lane, V.R. (2000). Fluid, fractured and distinctive? In search of a definition of organisational identity. Academy of Management Review, 25(1) 143-144. https://doi.org/10.5465/amr.2000.27711619

Sillince, J.A.A., \& Golant, B.D. (2018). Making connections: A process model of organisational identification. Human Relations, 71(3), 349-374. https://doi. org/10.5465/amr.2000.27711619

Van Tonder, C.L. (2004). At the confluence of organisational development (OD) and OI theory (OIT): Enter organisational interventions. SA Journal of Industria Psychology, 30(1), 91-98. https://doi.org/10.4102/sajip.v30i1.131

Veldsman, T.H. (2002). Forging excellence through and from change. In T.H. Veldsman (Ed.), Into the people effectiveness arena: Navigating between chaos and order (pp. 46-71). Johannesburg: Knowledge Resources.

Veldsman, T.H. (2016). The world of tomorrow: Leadership challenges, demands and requirements. In T.H. Veldsman \& A.J. Johnson (Eds.), Leadership: Perspectives from the front line (pp. 169-188). Johannesburg: KR Publishing.

Veldsman, T.H., \& Veldsman, D. (2020). Critically problematizing existing organisationa identity theory against practice: Part 1 - The thinking framework of organisationa identity. SA Journal of Industrial Psychology, 46(0), a1799. https://doi. org/10.4102/sajip.v46i0.1799

Zuckerman, E. (2016). Optimal distinctiveness revisited: An integrative framework for understanding the balance between differentiation and conformity in individual and organisational identities. In M.G. Pratt, M. Schultz, B.E. Ashforth, \& D. Ravash (Eds.), The Oxford handbook of organisational identity (pp. 183-197). Oxford: Oxford University Press. 